DOI: https://doi.org/10.31933/dijdbm.v2i2

Received: 26 November 2020, Revised: 20 December 2020, Publish: 4 March 2021

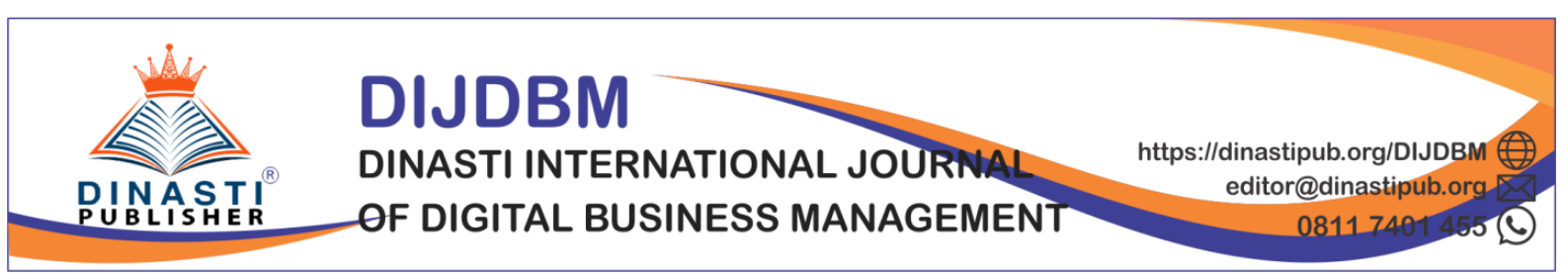

\title{
THE EFFECT OF COMPETENCY, ORGANIZATIONAL CITIZENSHIP BEHAVIOR AND WORK FAMILY CONFLICT ON EMPLOYEE PERFORMANCE AT THE SECRETARIAT DIRECTORATE GENERAL OF GUIDANCE ISLAMIC SOCIETY OF THE MINISTRY OF RELIGION OF THE REPUBLIC OF INDONESIA
}

\author{
Ihsan Bayu Merdeka ${ }^{1}$, Anik Herminingsih ${ }^{2}$, \\ ${ }^{1)}$ Master of Management Program,Postgraduate program, Mercubuana University Jakarta, \\ Indonesia, ibayici@gmail.com \\ ${ }^{2)}$ Master of Management Program,Postgraduate program, Mercubuana University Jakarta, \\ Indonesia, anik_herminingsih@gmail.com
}

Corresponding Author: Ihsan Bayu Merdeka

Abstract: This research aims to determine the effect of competence, Organizational Citizenship Behavior and work family conflict on the performance of employees at the Secretary General of Bimas Islam Indonesia. This type of research is descriptive quantitative, the method used is to distribute questionnaires to employees using a Likert scale, respondents used as many as 61 employees, using the SPSS 25 software program, data analysis was performed using validity, reliability and multiple linear regression correlation. The sampling technique obtained from a sample of 61 respondents, the data analysis technique used multiple linear regression. The results showed that; (1) Competence has a significant effect on employee performance; (2) Organizational Citizenship Behavior has a significant effect on employee performance; (3) work family conflict does not have a significant effect on organizational commitment.

Keywords: Competence, Organizational Citizenship Behavior, Work family conflict and Employee Performance

\section{INTRODUCTION}

Human resource management is an important thing that must be considered by organizations because humans are complex capital. Humans behave influenced by external and external factors. As previously mentioned, humans are organizational assets that, if managed properly, will not experience depreciation. Vice versa, if it is not managed properly it will be a boomerang for the organization itself. Therefore, it is very important to have a qualified human resource system so that organizational goals can be achieved and carried out properly. 
The Directorate General of Islamic Community Guidance, is a level I work unit within the Central Department of Religion. In the organizational nomenclature (regulated in the Regulation of the Minister of Religion Number 3 of 2006) of the Directorate General of Islamic Community Guidance, the name of this work unit is abbreviated as led by a Director General.

The main task of the Directorate General of Guidance for the Islamic Community is to formulate and implement policies in the field of Islamic community guidance in accordance with the provisions of laws and regulations. In running the organization, the Secretary General of Islamic Community Development each year has a performance target as a reference for activities for the next one year. Targets are set so that the institution can work properly, directed and measured.

The performance achievement at Bimas Islam until mid-2020 is still far from being achieved, this is due to the situation and working conditions where each individual must readjust the strategy in monitoring and evaluating the performance targets that were previously set at the beginning. The ability of individuals to manage emotions related to work family conflicts as well as extra competence and behavior in the organization are taken into consideration and are indications of impediments to the achievement of performance targets that do not move significantly until mid-2020.

In general, employee performance is influenced by many factors, each of which has a direct or indirect effect on organizational performance, according to Wibowo (2010: 100), employee performance is influenced by several factors as follows:

1. Personal factors, indicated by the level of skills, competencies, motivation and commitment.

2. Leadership factor, determined by the quality of encouragement, guidance and support provided by managers and team leaders.

3. Team factor, indicated by the quality of support provided by colleagues.

4. System factor, indicated by the work system and work facilities provided by the organization.

5. Situational factors, indicated by the high level of pressure and changes in the internal and external environment.

From the description above, the researcher decided to conduct a pre-survey of 20 employees at the Secretary General of Community Development to find out the problems that exist in the BIMAS Islam organization.

The results of the pre-survey indicated that there were several problems experienced by the respondents. As many as $75 \%$ of respondents stated that they experienced domestic conflicts with work and they could not do their friend's work if they were unable to attend. This statement indicates that there is a work family conflict problem. Another $75 \%$ stated that the level of organizational citizenship behavior was in poor condition. Meanwhile, the questions regarding their competence at work showed that $60 \%$ disagreed that they felt they had sufficient ability to carry out the job. This provides an illustration that there are problems with work competence.

Based on the description of the phenomenon above, the researcher thinks it is necessary to conduct a study entitled "The Effect of Competence, Organizational Citizenship Behavior and Work Family Conflict on Employee Performance at the Secretariat of the 
Directorate General of Islamic Community Guidance at the Ministry of Religion of the Republic of Indonesia".

\section{LITERATURE REVIEW Competency}

According to Spencer and Spencer in Moeheriono (2012) competence is a characteristic that underlies a person related to the effectiveness of individual performance in their work or the basic characteristics of individuals who have a causal relationship or as a cause-and-effect with criteria that are used as references, are effective or perform at prime or superior in the workplace. or in certain situations. Competence is the basis for how the work performed by employees can be carried out in accordance with the demands of the work for which they are responsible. In this case, employees must continue to be able to adjust to be able to have the will so that they meet competency standards in accordance with their field of work. Lasmahadi (2002) also states that competence will always be associated with superior performance since competence includes personal aspects that encourage employees to achieve superior performance. Competence includes a set of intelligent actions, full of responsibility that a person has as a condition to be considered capable by the community or the surroundings in carrying out tasks in the field of work.

Another opinion was expressed by Wibowo (2014: 271) which defines competence as the ability to perform or carry out a job or task based on skills and knowledge and is supported by the work attitude demanded by the job. Competence indicates the characteristics of the knowledge and skills that individuals possess or need to enable them to carry out their duties and responsibilities effectively and to raise the standards of professional quality in their work.

From some of the definitions of competence above, it can be concluded that competence is defined as the ability that must be possessed by an employee or to carry out a job to the maximum (effective, efficient, productive and meet the requirements) in accordance with the intended organization / leader.

\section{Organizational Citizenship Behavior (OCB)}

Organizational Citizenship Behavior (OCB) is part of the science of organizational behavior, OCB which is usually not seen or taken into account. There are two approaches to the concept of $\mathrm{OCB}$, namely $\mathrm{OCB}$, which is an extra role performance that is separate from in-role performance or performance that matches the job description. The second approach is to view OCB from a political principle or philosophy. This approach identifies the behavior of organizational members with citizenship behavior. The existence of OCB is the impact of the beliefs and perceptions of individuals in the organization on the fulfillment of psychological agreements and contracts. This behavior arises because of the feeling of individuals as organizational members who feel satisfied if they can do something more than the organization (Saleem and Amin, 2013).

The behavior or role performed by employees is very important for a company. Various opinions expressed about the importance of employee behavior who want to work beyond the existing job description, among others, as stated by Robbins (Robbins and Judge, 2015) which states that successful organizations need employees who will do more than just their formal duties and are willing to provide performance that exceeds expectations. In today's dynamic world of work, where tasks are increasingly being done in teams, flexibility 
is very important. Organizations want employees who are willing to perform tasks that are not listed in their job descriptions (Robbins and Judge, 2015). According to Robbins and Judge (2015), the facts show that organizations that have employees who have good OCB will have better performance than other organizations.

From some of the definitions of the characters above, it can be concluded that OCB is a voluntary behavior, not a forced action on matters that prioritize organizational interests. Individual behavior as a form of satisfaction based on performance is not formally ordered

\section{Work family conflict}

Several theories define the term conflict differently. Rivai and Sagala, (2011: 999) describe conflict as differences or differences, conflicts and disputes between one or more members or groups (organized / company), as a result of differences in status, goals, values, and perceptions. According to (Wirawan 2010: 5) conflict is a process of conflict expressed between two or more parties who depend on each other on the object of the conflict, using patterns of conflict behavior and interactions that give rise to conflict. In addition, Usman (2013: 504) mentions conflict as a conflict between two members of an organization, an individual, and self-conflict against something. Conflict is also defined as that opposites between individuals or groups that can lead to tension and obstacles in achievement goals.

The indicators used by Tabassum, in Ayesha (2012) to examine family-work conflicts are spouse and family support. Meanwhile, Wallace (2015) uses social support as measured by four variables, namely peer support, organizational support, partner support (emotional), and partner support (career). Work family conflict is defined as a form of role conflict in which pressures from work and family domains are incompatible in some way (Greenhaus and Beutell, 1985). This term can be illustrated as how someone who has a dual role, parents and professional auditors, has conflicts in the family environment and their professional responsibilities. Recent studies suggest that work-family conflict has two perspectives in defining conflict; they are a family that interferes with work and jobs that disturb the family. This two-dimensional perspective on conflict was established by previous researchers.

\section{Employee Performance}

According to Lestari (2016: 36) "Performance is something that is displayed by a person or a process related to assigned work tasks. Performance is not the last end of a series of work processes but an overall view that starts from the elements of the process input activities, outputs and outcome materials.

According to the Indonesian Dictionary (2008: 700), performance is defined as something that can be achieved, demonstrated achievement, ability to work. According to Moeheriono (2012: 95), performance is a description of the achievement of the level of implementation of an activity or work program. Meanwhile, Kirkpatrick and Nixon (Sagala, 2011: 179) said that performance is a measure of success in achieving the goals that have been set or planned. Rivai and Sagala (2011: 548-549) state that performance is real behavior as an achievement produced by employees in accordance with their role in the organization.

Performance can also be described as human activity in carrying out the main tasks given to him, Patricia King (Sembiring, 2012: 81). Meanwhile, Wirawan (2012: 5) performance is the output resulting from a function or indicator of a job or profession within a certain period of time. The elements or indicators used as a measuring tool for employee 
performance according to Mathis and Jackson (2011: 378) include the quantity of work, quality of work, and work timeline, attendance and ability to work together. Meanwhile, according to Lamatenggo (2012: 71) performance measurement criteria consist of five indicators, namely quality of work, speed and accuracy, work initiative, ability to work, and ability to communicate at work.

\section{Previous Research}

This research is based on several previous studies. In the research of Sukmayanti et al. (2016) entitled The Influence of Intellectual Competence and Employee Career Development on Employee Performance (Studies at PT. Wija Kusuma Nadi) show that competence has a positive and significant effect on performance. In Lestari \& Ghaby's (2018) study entitled The Effect of Organizational Citizenship Behavior (OCB) on Job Satisfaction and Employee Performance, it shows that OCB has a significant positive effect on job satisfaction and employee performance. Then research conducted by Maria (2017) entitled The Impact of Work-family Conflict toward Job Performance-The Case of External Auditor shows that work family conflict has a negative and significant effect on employee performance.

\section{Conceptual Framework and Hypotheses}

Based on the study of the theory and previous research, it is composed framework and hypotheses as follows:

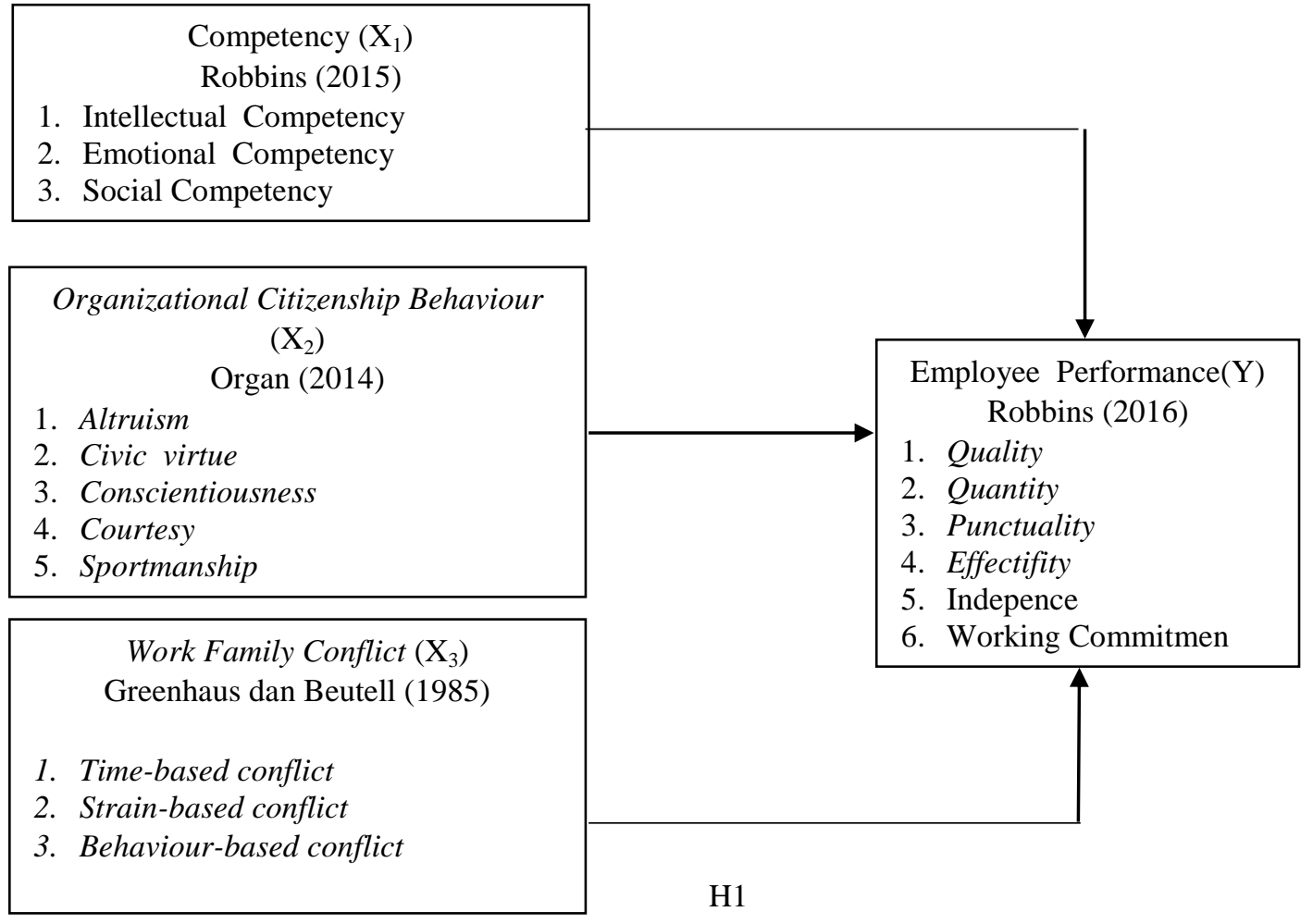

Figures 1. Conceptual Framework

\section{Hipotesis}


H.1 Competence has a significant effect on employee performance at the Secretary General of Islamic Community Guidance

H.2 Organizational citizenship behavior has a significant effect on employee performance at the Secretary General of Islamic Community Guidance

H.3 Work family conflict has a significant effect on the performance of employees at the Secretary General of Islamic Community Guidance

\section{RESEARCH METHOD}

The type of research that will be carried out by the author is descriptive quantitative, with quantitative data collection methods and using survey methods. According to Arikunto (2015: 3) descriptive research is research that is intended to investigate circumstances, conditions or other things that have been mentioned, the results of which are presented in the form of a research report.

The population in this study were all 61 employees at the Secretariat of the Directorate General of Islamic Community Guidance. Given that the population is less than 100, the total sample is taken as a whole. Thus the use of the entire population without having to draw the research sample as a unit of observation is called a census technique. To collect research data, a questionnaire was chosen as the data collection method in this study.

Data analysis in this study used quantitative data analysis techniques, namely by using correlation analysis and multiple linear regression. The first thing to do is to test the instrument on the questionnaire or instrument to be used. The questionnaire or instrument is distributed or given to several respondents to be completed and the results will be tested by validity and reliability tests. Data that can be added, multiplied, subtracted and divided is only data that is at least on an interval scale, so that if the research variables are measured on an interval scale, it fulfills one of the initial requirements using parametric statistical analysis.

\section{FINDING AND DISCUSSION Deskripsi Responden}

As in Table 1, it can be seen that the characteristics of respondents based on age, gender, education and years of service of the respondent. When viewed from the age level, the majority of respondents were $>33$ years old, namely 50 people (82\%). From the sex of male respondents more than women, namely at $64 \%$ (39 people) of men. Then when viewed from the education level of the respondents, the majority of employees have an undergraduate education, namely 50 people $(82 \%)$.

Table 1. Respondent Description

\begin{tabular}{clcc}
\hline No & Characteristic & Total & Percentage \\
\hline 1. & Age & 11 & \\
& $28-32$ years old & 50 & $18 \%$ \\
& $>33$ years old & 61 & $82 \%$ \\
& Total & & $100 \%$ \\
\hline 2. & Gender & 39 & $64 \%$ \\
& Male & 22 & $36 \%$ \\
& Female & 61 & $100 \%$ \\
\hline & Total & & \\
\hline
\end{tabular}




\begin{tabular}{llcc}
\hline 3. & Education & & \\
& S1 & 50 & $82 \%$ \\
S2 & 10 & $16 \%$ \\
& S3 & 1 & $2 \%$ \\
& Total & 61 & $100 \%$ \\
\hline $4 . \quad$ Working Time & & \\
& $\leq 5$ years & 19 & $31 \%$ \\
& D years & 42 & $69 \%$ \\
& Total & 61 & $100 \%$ \\
\hline
\end{tabular}

Source: Processed Research Data (2020)

Based on the length of work, respondents with a working period of more than 5 years were 42 respondents or $69 \%$ and followed by a working period of less than 5 years as many as 19 respondents or $31 \%$. This shows that the tenure of employees in the organization is quite experienced in dealing with problems in the organization

\section{Variable Description}

Based on Table 2, it can be seen that from the respondent's perception of the Competency variable, the Social Competence dimension has the highest average value of 3.35 and the lowest average perception is in the Intellectual Competence dimension with a value of 3.09. In research in the OCB variable, it can be seen that from the respondent's perception of the Organizational Citizenship Behavior variable, the Altruism dimension has the highest average value with a value of 3.33 and the lowest average perception is in the Courtesy dimension with a value of 2.86. On the respondent's perception of the Work Family Conflict variable, the Strain based conflict dimension has the highest average value of 3.48 and the lowest average perception is in the Behavior based conflict dimension with a value of 3.16. Then on the respondent's perception of the employee performance variable, punctuality dimension has the highest average value with a value of 3.70 and the lowest average perception is in the work commitment dimension with a value of 2.33 . Overall the dimensions of the research variables are in the category that still needs improvement, especially employee performance.

Table 2. Descriptive Statistics of Competency Variables, Organizational citizenship behavior, Work family conflict and employee performance

\begin{tabular}{lccccc}
\hline \multicolumn{1}{c}{ Question } & $\begin{array}{c}\text { Total } \\
\text { Respondent }\end{array}$ & $\begin{array}{c}\text { Responses } \\
\text { Minimum }\end{array}$ & $\begin{array}{c}\text { Responses } \\
\text { Maximum }\end{array}$ & Average & $\begin{array}{c}\text { Standard } \\
\text { Deviation }\end{array}$ \\
\hline Competence & & & & & \\
\hline Intellectual Competence & 61 & 1 & 5 & 3,09 & 1,09 \\
Emotional Competence & 61 & 1 & 5 & 3,16 & 1,09 \\
Sosial Competence & 61 & 1 & 5 & 3,35 & 1,16 \\
\hline Organizational citizenship behavior & 61 & 1 & 4 & 3,33 & 1,15 \\
\hline Altruism & 61 & 1 & 5 & 3,08 & 0,56 \\
Civic Virtue & 61 & 1 & 5 & 3,25 & 0,92 \\
Conscientiousness & 61 & 1 & 5 & 2,86 & 0,68 \\
Courtesy & 61 & 1 & 5 & 3,24 & 0,89 \\
Sportmanship & & & & & \\
\hline Work family conflict & 61 & 1 & 4 & 3,18 & 1,02 \\
\hline Time based conflict & 61 & 1 & 5 & 3,48 & 0,93 \\
Strain based conflict & 61 & 1 & 5 & 3,16 & 1,09 \\
Behavior based conflict & & & & & \\
\hline Employee Performance & & & & &
\end{tabular}

Employee Performance 


\begin{tabular}{|c|c|c|c|c|c|}
\hline Quality & 61 & 1 & 5 & 3,16 & 0,86 \\
\hline Quantity & 61 & 1 & 5 & 3,42 & 1,15 \\
\hline Punctuality & 61 & 1 & 5 & 3,70 & 0,88 \\
\hline Efectifitty & 61 & 1 & 5 & 2,80 & 1,14 \\
\hline Independence & 61 & 1 & 5 & 3,49 & 0,98 \\
\hline Work Commitment & 61 & 1 & 5 & 2,33 & 0,59 \\
\hline
\end{tabular}

\section{Result}

\section{Validity}

By using the Pearson Correlation Method (Product Moment Person), the basis for decision making is if $r$ count $>r$ table then the statement is valid and if $r$ count $<r$ table then the statement is invalid.

The calculated $r$ value is obtained from the calculation using SPSS 25 software and a predetermined formula, while the $\mathrm{r}$ table value is obtained from the r-product moment table with a significance level of 5\%. With a significance level of 5\% and the number of respondents as many as 61 people $(\mathrm{N})$, the $\mathrm{r}$ table value is $=0.2241$ for all independent and dependent variables, while the rcount value is obtained from the calculation results shown in Table 3

Table 3. Test the Validity of the variant $X_{1}, X_{2}, X_{3}$ and $Y$

\begin{tabular}{|c|c|c|c|c|}
\hline \multirow[t]{2}{*}{ Variable } & \multirow{2}{*}{ Dimention } & Pearson & \multirow[t]{2}{*}{$\mathbf{r}_{\text {tabel }}$} & \multirow[t]{2}{*}{ Conclusion } \\
\hline & & ( $\mathrm{r}_{\text {hitung }}$ ) & & \\
\hline \multirow[t]{3}{*}{ COMPETENCY } & Intellectual Competence & 0,5855 & 0,2480 & Valid \\
\hline & Emotional Competence & 0,4625 & 0,2480 & Valid \\
\hline & Social Competence & 0,7311 & 0,2480 & Valid \\
\hline \multirow{5}{*}{$\begin{array}{c}\text { ORGANIZATIONAL } \\
\text { CITIZENSHIP BEHAVIOR }\end{array}$} & Altruism & 0,6971 & 0,2480 & Valid \\
\hline & Civic Virtue & 0,3050 & 0,2480 & Valid \\
\hline & Conscientiousness & 0,4995 & 0,2480 & Valid \\
\hline & Courtesy & 0,3380 & 0,2480 & Valid \\
\hline & Sportmanship & 0,5000 & 0,2480 & Valid \\
\hline \multirow{3}{*}{$\begin{array}{c}\text { WORK FAMILY } \\
\text { CONFLICT }\end{array}$} & Time-based conflict & 0,5300 & 0,2480 & Valid \\
\hline & Strain-based conflict & 0,6060 & 0,2480 & Valid \\
\hline & Behavior-based conflict & 0,6775 & 0,2480 & Valid \\
\hline \multirow{6}{*}{$\begin{array}{c}\text { EMPLOYEE } \\
\text { PERFORMANCE }\end{array}$} & Quality & 0,4605 & 0,2480 & Valid \\
\hline & Quantity & 0,5850 & 0,2480 & Valid \\
\hline & Puncuality & 0,5280 & 0,2480 & Valid \\
\hline & Efectifitty & 0,2145 & 0,2480 & Not Valid \\
\hline & Independence & 0,4305 & 0,2480 & Valid \\
\hline & Work Commitment & 0,2650 & 0,2480 & Valid \\
\hline
\end{tabular}

\section{Reliabilitas}

The method of testing reliability in this study is by testing Cronbach's Alpha (with SPSS 25 Software) and a variable can be declared reliable if it produces a Cronbach Alpha value> 0.6. Reliability test results can be shown through. below this :

Table 4. Reliability Test of Measurement Instruments

\begin{tabular}{lc}
\hline \multicolumn{1}{c}{ Variabel } & Cronbach's Alpha \\
\hline Competency & 0,733 \\
Organizational citizenship behavior & 0,709
\end{tabular}




\begin{tabular}{ll} 
Work family conflict & 0,741 \\
Employee Performance & 0,694 \\
\hline
\end{tabular}

Source: Researcher's Results Processed (2020)

\section{Multiple Linear Analysis}

Following are the results of data processing on respondents' assessments regarding the effect of commitment, organizational citizenship behavior and work family conflict on the performance of the employees of the Secretary General of the Indonesian Islamic Community Guidance, with a total of 61 respondents

Tabel 5. Multiple Linear Analysis

Coefficients $^{\text {a }}$

\begin{tabular}{|c|c|c|c|c|c|c|}
\hline \multirow[b]{2}{*}{ Model } & & \multicolumn{2}{|c|}{ Unstandardized Coefficients } & \multirow{2}{*}{$\begin{array}{c}\begin{array}{c}\text { Standardized } \\
\text { Coefficients }\end{array} \\
\text { Beta }\end{array}$} & \multirow[b]{2}{*}{$\mathrm{t}$} & \multirow[b]{2}{*}{ Sig. } \\
\hline & & $\mathrm{B}$ & Std. Error & & & \\
\hline \multirow[t]{4}{*}{1} & (Constant) & 1,019 & 0,261 & & 3,903 & 0,000 \\
\hline & Competency & 0,310 & 0,109 & 0,458 & 2,856 & 0,006 \\
\hline & $\begin{array}{l}\text { Organizational } \\
\text { citizenship behavior }\end{array}$ & 0,271 & 0,100 & 0,280 & 2,725 & 0,009 \\
\hline & Work family conflict & 0,090 & 0,097 & 0,142 & 0,933 & 0,355 \\
\hline
\end{tabular}

a. Dependent Variable: Employee Performance

Source: Research Data Processed (2020)

$\mathrm{Y}=1,019+0,310 \mathrm{X}_{1}+0,271 \mathrm{X}_{2}+0,090 \mathrm{X}_{3}+\mathrm{e}$

Description:

$\mathrm{Y}=$ Employee Performance

$\mathrm{X}_{1}=$ Competency

$\mathrm{X}_{2}=$ Organizational citizenship behavior

$\mathrm{X}_{3}=$ Work family conflict

e $=$ Residual Error

The conclusion of the regression equation above is as follows:

1. A constant of 1.019 states that, if the competency variable (X1), Organizational citizenship behavior (X2) and Work family conflict (X3) is 0 , then the employee performance at the Secretary General of Bimas Islam Indonesia is 1.019

2. The regression coefficient of $\mathrm{X} 1$ for the Competency variable is 0.310 , which states that every 1 addition to the Competency value, the Employee Performance will increase again by 0.310 .

3. The regression coefficient $\mathrm{X} 2$ of the Organizational Citizenship Behavior variable is 0.271 , which states that every addition of 1 value for Organizational Citizenship Behavior, the employee performance will increase again by 0.271 .

4. The regression coefficient X3 for the work family onlict variable is 0.090 , which states that every addition of 1 value for organizational citizenship behavior, the employee's performance increases again by 0.090 . 
Based on the data above, it can be concluded that the independent variable that has the greatest positive contribution to employee performance is organizational citizenship behavior, so also the competency variable has a positive but insignificant effect and work family conflict also has a positive contribution although not as large as the organizational citizenship behavior variable.

Table 6. Simultaneous Testing Analysis (Test F)ANOVA ${ }^{\text {a }}$

\begin{tabular}{|c|c|c|c|c|c|c|}
\hline Model & & $\begin{array}{l}\text { Sum of } \\
\text { Squares }\end{array}$ & df & Mean Square & $\mathrm{F}$ & Sig. \\
\hline \multirow[t]{3}{*}{1} & Regression & 11,154 & 3 & 3,718 & 29,900 &, $000^{b}$ \\
\hline & Residual & 7,088 & 57 &, 124 & & \\
\hline & Total & 18,242 & 60 & & & \\
\hline
\end{tabular}

a. Dependent Variable: Average Performance

b. Predictors: (Constant), Average komp, An OCB, Average wfc

Source: Research Results (2020)

From Table 6, it is obtained that the fcount is 29,900. Then compared with a significant level of $5 \%$ and df $1=\mathrm{k}-1$ or $5-1=4$ and df $2=\mathrm{n}-\mathrm{k}$ or $61-4=57$ then df 57 is 2.66487. Thus, it can be concluded that the value of fcount> ftabel or 29.900>2.66487, where the significant value is $0.000<0.05$. It means that Ho is rejected and Ha is accepted, meaning that there is a significant influence between competence (X1), Organizational citizenship behavior (X2) and Work family conflict (X3) on employee performance (Y).

\section{Coefficient of Determination (R2)}

Testing the coefficient of determination (R2) is used to measure the proportion or percentage of the model's ability to explain the dependent variable. The coefficient of determination ranges from zero to one $(0 \leq \mathrm{R} 2 \leq 1)$. If $\mathrm{R} 2$ is greater (close to one), it can be said that the influence of the independent variable $(\mathrm{X})$ is large on the dependent variable $(\mathrm{Y})$. This means that the model used is getting stronger to explain the effect of the independent variables on the dependent variable and vice versa.

Table 7. Data Analysis The Coefficient Of Determination $\left(\mathbf{R}^{2}\right)$ Model Summary ${ }^{\mathrm{b}}$

\begin{tabular}{|c|c|c|c|c|c|}
\hline Model & $\mathrm{R}$ & R Square & $\begin{array}{l}\text { Adjusted } \mathrm{R} \\
\text { Square }\end{array}$ & $\begin{array}{c}\text { Std. Error of the } \\
\text { Estimate }\end{array}$ & Durbin-Watson \\
\hline 1 &, $782^{\mathrm{a}}$ & ,611 & ,591 & ,35263 & 2,549 \\
\hline
\end{tabular}

a. Predictors: (Constant), Competence, Organizational citizenship behavior, Work family conflict

b. Dependent Variable: Performance

\section{Source: Research Results (2020)}

Based on the results of primary data processing using the SPSS version 25.0 program, the $\mathrm{R} 2$ coefficient is 0.611 . This shows that the percentage of the contribution of independent variables (competence, organizational citizenship behavior, and work family conflict) is able to explain the dependent variable performance $(\mathrm{Y})$ of $61.10 \%$ while the remaining $37.90 \%$ is explained by other variables not included in this study. . It can be concluded that collectively the independent variables have an effect of $61 \%$, meaning that more than $50 \%$ of employee performance in the Setjen Bimas Islam is influenced by competence, the extra behavior of each employee and the management of family conflicts with work also affects the individual performance achievement of BIMAS General Secretariat Islam. 


\section{Discussion}

The t-test is used to determine whether or not a partially influences the independent variable or a dependent variable is significant or not. To test this hypothesis, first look for starting $t$ count using SPSS V.25 then compared with the $\mathrm{t}$ table value, while the hypothesis is as follows:

Ho: There is no significant influence between the independent and dependent variables (Ho is accepted and $\mathrm{Ha}$ is rejected, if the value of tcount <ttable).

Ha: There is a significant influence between the independent variable and the dependent variable (Ho is rejected and $\mathrm{Ha}$ is accepted, if the value of tcount $>$ ttable). Based on the results of data acquisition using SPSS V.25, the output value can be obtained in the table

Table 8. The results of the Calculation and verification of the Hypothesis (Uji $t)$

\begin{tabular}{lccc}
\hline \multicolumn{1}{c}{ Relationship Structure } & Partial Correlation & Sig Value & Hipotheses \\
\hline $\begin{array}{l}\text { Competence on Employee } \\
\text { Performance }\end{array}$ & 0,310 & 0,006 & Ha Accepted \\
\hline $\begin{array}{l}\text { Organizational Citizenship } \\
\text { Behavior on Employee } \\
\text { Performance }\end{array}$ & 0,271 & 0,009 & Ha Accepted \\
\hline $\begin{array}{l}\text { Work Family Conflict on } \\
\text { Employee Performance }\end{array}$ & 0,090 & 0,355 & Ha Rejected \\
\hline
\end{tabular}

1. The influence of competence on employee performance in this study can be seen from table 8 where the significance value obtained is 0.006 less than 0.05 , which means that $\mathrm{Ha}$ is accepted, that is, it can be concluded that there is a significant positive effect between competence on employee performance

2. The influence of Organizational Citizenship Behavior on Employee Performance in this study can be seen from table 8 where the significance value obtained is 0.009 less than 0.05 , which means that $\mathrm{Ha}$ is accepted, that is, it can be concluded that there is a significant positive effect between Organizational Citizenship Behavior on Employee Performance.

3. The effect of Work Family Conflict on Employee Performance in this study can be seen from table 8 where the significance value obtained is 0.355 greater than 0.05 , which means that $\mathrm{Ha}$ is rejected, that is, it can be concluded that there is a positive but insignificant influence between Work Family Conflict on Employee Performance.

\section{Multidimension Correlation}

To find out which dimension of the independent variable is the most dominant and its influence on the dimensions of the dependent variable, the inter-dimensional correlation matrix is used. Based on Table 9, it can be concluded that a strong relationship between dimensions is as follows:

1. The influence of competence on employee performance, the results obtained by the calculation of data with the strongest correlation are in the variable relationship between the dimensions of social competence (X1.3) and the quantity of work (Y2) with $r=0.768$.

2. The influence of the influence of organizational citizenship behavior on employee performance, then the greatest correlation is found in the relationship between dimensions 
of altruism (X2.1) with timeliness (Y3) with $\mathrm{r}=0.779$

3. The effect of work family conflict on organizational commitment, then the greatest correlation is found in the relationship between the dimensions of Time Based Conflict (X3.1) and work quality (Y1) with $r=0.763$

Table 9. Result of Dimensional Correlation Matrix

Between Independent Variables and Bound Variables

\begin{tabular}{|c|c|c|c|c|c|c|}
\hline \multirow[b]{2}{*}{ Dimension } & \multicolumn{6}{|c|}{$\begin{array}{l}\text { Employee Performance Variable }(\mathbf{Y}) \\
\end{array}$} \\
\hline & Work quality & Work quality & Work quality & Work quality & Work quality & Work quality \\
\hline $\begin{array}{l}\text { Intellectual } \\
\text { Competence } \\
\text { (X1.1) }\end{array}$ & 0,652 & 0,359 & 0,263 & 0,052 & 0,054 & 0,104 \\
\hline $\begin{array}{l}\text { Emotional } \\
\text { Competence } \\
\text { (X1.2) }\end{array}$ & 0,651 & 0,365 & 0,408 & $-0,127$ & 0,256 & 0,085 \\
\hline $\begin{array}{l}\text { Social } \\
\text { Competence } \\
\text { (X1.3) }\end{array}$ & 0,448 & 0,768 & 0,295 & 0,109 & 0,160 & 0,071 \\
\hline \multicolumn{7}{|c|}{ Competency Variable (X1) } \\
\hline Altruism $\left(\mathrm{X}_{2.1}\right)$ & 0,484 & 0,370 & 0,779 & $-0,230$ & 0,424 & 0,038 \\
\hline $\begin{array}{l}\text { Civic Virtue } \\
\left(\mathrm{X}_{2.2}\right)\end{array}$ & 0,586 & 0,716 & 0,675 & -0.076 & 0,367 & 0,069 \\
\hline $\begin{array}{l}\text { Conscientiousn } \\
\text { ess }\left(X_{2.3}\right)\end{array}$ & 0,545 & 0,145 & 0,412 & $-0,097$ & 0,129 & 0,157 \\
\hline Courtesy $\left(\mathrm{X}_{2.4}\right)$ & 0,220 & 0,247 & 0,209 & 0,024 & 0,223 & 0,174 \\
\hline $\begin{array}{l}\text { Sportmanship } \\
\left(\mathrm{X}_{2.3}\right)\end{array}$ & 0,429 & 0,399 & 0,313 & 0,023 & 0,095 & 0,060 \\
\hline \multicolumn{7}{|c|}{ Organizational citizenship behavior Variable (X2) } \\
\hline $\begin{array}{l}\text { Time-based } \\
\text { conflict }\left(\mathrm{X}_{3.1}\right)\end{array}$ & 0,763 & 0,378 & 0,366 & 0,049 & 0,167 & 0,137 \\
\hline $\begin{array}{l}\text { Strain-based } \\
\text { conflict }\left(\mathrm{X}_{3.2}\right)\end{array}$ & 0,561 & 0,636 & 0,415 & $-0,110$ & 0,227 & 0,039 \\
\hline $\begin{array}{l}\text { Behavior-based } \\
\text { conflict }\left(\mathrm{X}_{3.3}\right)\end{array}$ & 0,651 & 0,365 & 0,415 & $-0,127$ & 0,256 & 0,085 \\
\hline
\end{tabular}

Source: Processed Research Data (2020)

\section{CONCLUSIONS AND SUGGESTIONS Conclusion}

This study was intended to determine the effect of competence, organizational citizenship behavior, and work family conflict on employee performance. Based on the results of research and discussion, the authors can draw the following conclusions: Competence has a positive and significant effect on the performance of employees at the Secretariat General of Indonesian Islamic Community Guidance, there is a significant influence between organizational citizenship behavior on employee performance with the strongest dimensions, namely altruism and timeliness, no. There is a significant effect between work family conflict on employee performance, indicating that employees can manage life in the office and at home properly, this means that in carrying out daily activities, data duties and authority are separated from conflicts that occur outside of work. 


\section{Suggestion}

Based on the above conclusions, the authors can provide some suggestions that are expected to be positive input for the Secretariat General of Islamic Community Development: Secretary General Bimas can consider re-designing training and grouping and $\mathrm{HR}$ management in it so that all competency and performance targets can be arranged to achieve Organizational goals that are more focused and have more competitiveness in fighting for people's rights to get the best service from state servants in the field of religious services, the workload at the Secretary General of Bimas should consider the time and competence of each employee, organizational performance can be supported by individual competence and behavior loyal extra formed from the implementation of a qualified HR strategy. Therefore, it is expected that by strengthening competence and responding with good feedback from all elements, organizational goals can be achieved.

\section{REFERENCE}

Ahmed M., Muddasar M. \& Perviaz S., 2012, 'The impact of work-family conflict and pay on employee job satisfaction with the moderating effect of perceivedsupervisor support in Pakistan banking sector', Global Journal of Management \& Business Research 12(6), 8.

Arikunto. 2015. Prosedur Penelitian Suatu Pendekatan Praktik. Jakarta: Rineka Cipta

Bagia, Wayan. (2015). Perilaku Organisasi. Yogyakarta : Graha Ilmu.

Bandari, Ani Supra. (2016). Peranan Pelatihan dalam Meningkatkan Kinerja Pegawai pada Unit Perencanaan PDAM Tirta Musi Rambutan. Jurnal Manajemen Sumber Daya Manusia, 10-21.

Distyawaty, D. (2017). Pengaruh Kompetensi Dan Pengembangan Karir TerhadapKinerja Aparatur Pengawas Inspektorat Daerah Provinsi Sulawesi Tengah. Jurnal Katalogis, $5(4), \quad 56-68$.

Dusauw, A., Lengkong, V. dan Sendow, G. 2016. Pengaruh Pelatihan, Keterlibatan Kerja dan Kompetensi Terhadap Kinerja Pegawai PadaPT. Bank Sulut Go Manado. Jurnal EMBA. Vol.4 No.5

E. R. Lestari, N. Kholifatul, and F. Ghaby, "Pengaruh Organizational Citizenship Behavior $(O C B)$ terhadap Kepuasan Kerja dan Kinerja Pegawai The Influence of Organizational Citizenship Behavior (OCB) on Employee'sJob Satisfaction and Performance," J. Teknol. dan Manaj. Agroindustri, 2018.

Ghozali, Imam. 2016. Aplikasi Analisis Multivariete Dengan Program IBM SPSS 23 (Edisi 8). $\quad$ Cetakan ke VIII. Semarang : Badan Penerbit Universitas Diponegoro.

Gibson, Edward. (2006). Emotional influences on food choice: Sensory, physiological and psychological pathways. Physiology \& behavior.89. 53-61.

10.1016/j.physbeh.2006.01.024.

Greenhaus, J. H., \& Beutell, N. J. (1985). Sources of Conflict Between Work and Family Roles. Academy of Management Review, 10(1), 76-88. doi:10.5465/amr.1985.4277352 
Hutapea, Parulian dan Nurianna Thoha. (2008). Kompetensi Plus. Jakarta, PT Gramedia Pustaka Utama.

Istijanto, 2014. Riset Sumber Daya Manusia Cara Praktis Mendeteksi Dimensi dimensi Kerja Pegawai. Jakarta: PT. Gramedia Pustaka Utama.

Martono, Nanang. 2015. Metode Penelitian Sosial. Jakarta: Rajawali Pers.

Mangkunegara, Anwar Prabu. (2012). Manajemen Sumber Daya Manusia. Bandung: $\quad$ PT. Remaja Rosdakarya.

Moeheriono. (2012). Pengukuran Kinerja Berbasis Kompetensi:Edisi Kedua. Jakarta: PT. Raja Grafindo Persada.

Nawawi, Hadari. (2006). Evaluasi dan manajemen kinerja di lingkungan perusahaan dan industri. Yogyakarta: Gadjah Mada Univercity Press.

Nguyen, P. T., Arifani, A. Z. T., Susanti, A. Y., \& Mahaputra, M. R. (2020). LITERETURE REVIEW FACTORS AFFECTING EMPLOYEE PERFORMANCE: COMPETENCE, COMPENSATION AND LEADERSHIP. Dinasti International Journal of Economics, Finance \& Accounting, 1(3), 538-549.

Organ, D. W. (2014). Organizational citizenship behavior: The good soldier syndrome. Lexington, MA: Lexington Books.

Palan (2007) Competency Management: Teknis MengimplementasikanManajemen SDM Berbasis Kompetensi untuk Meningkatkan Daya Saing Organisasi. PPM: Jakarta.

Pamularso, Eigis Yani. (2018). Pengaruh Kompetensi terhadap Kinerja Pegawai CV Inaura Anugerah Jakarta. Widya Cipta Vol II, No. 1

Putri, Yumna Dalian dan Utami, Hamidah Nayati. 2017. Pengaruh Organizational Citizenship Behavior $(O C B)$ terhadap Kinerja. Jurnal Administrasi Bisnis (JAB), Vol. 46(1): 2734.

Rivai, Veithzal dan Sagala, Ella Jauvani. (2011). Manajemen Sumber Daya untuk Perusahaan dari Teori ke Praktik. Jakarta: PT Raja Grafindo.

Robbins, Stephen P. (2015). Perilaku Organisasi. Jakarta Selatan: Salemba Empat.

Roboth Y. Jane. 2013. Analisis Work family conflict, Stres Kerja Dan Kinerja Wanita Berperan Ganda Pada Yayasan Compassion East Indonesia.Program Magister Manajemen Fakutas Ekonomi Dan Bisnis. Universitas Sam Ratulangi. Manado.

Saleem, Sharjeel and Saba Amin. (2013). The Impact of Organizational Support for Career Development and Supervisory Suppoert on Employee Performance :

An Emperical Study From Pakistani Academic Sector. Europen Journal of Business and Management. 5 (5), pp: 194-207.

Sembiring, Masana. (2012). Budaya dan Kinerja Organisasi. Bandung: Fokus Media

Sugiyono. (2016). Metode Penelitian Kuantitatif, Kualitatif dan R\&D. Bandung: PT Alfabet. 
Sukmayanti, N. L. P., Bagia, I. W., \& Suwendra, I. W. 2016. Pengaruh Intelektual E-Jurnal Bisma
Dan

$$
\begin{aligned}
& \text {, I. W., \& Suwendra, I. W. 2016. Pengaruh } \\
& \text { Pengembangan Karir Pegawai Terhadap }
\end{aligned}
$$$$
\text { Universitas Pendidikan Ganesha. }
$$

Kompetensi

KinerjaPegawai.

Vol.4 (1), hal 1-8.

Tabassum, Ayesha. (2012). Interrelations between Quality of Work Life Dimensions and Faculty Member Job Satisfaction in the Private Universities European Journal of Business and Management. 4.

Usman, Hunaini. (2013). Manajemen: Teori, Praktik dan Riset Pendidikan Ed 4. Jakarta: Bumi Aksara.

Wallace, Jean \& Lemaire, Jane. (2009). Physician well being and quality of patient care: An exploratory study of the missing link. Psychology, health \& medicine. 14. 545-52. 10.1080/13548500903012871.

Wang, M.-L., \& Tsai, L.-J. (2014). Work-Family Conflict and Job Performance in Nurses. Journal of Nursing Research, 22(3), 200-207. doi:10.1097/jnr.0000000000000040

Wibowo. (2013). Manajemen Kinerja. Jakarta: Rajawali Pers.

Wibowo . (2014) . Perilaku Dalam Organisasi . Edisi 1-2 . Jakarta : Rajawali Pers.

Wirawan. (2010). Konflik dan Manajemen Konflik: Teori. Aplikasi, dan Penelitian. Jakarta: $\quad$ Salemba Humanika. 